ARTICLE

DOI: $10.1038 / s 41467-018-06043-1$

\title{
Dendritic defect-rich palladium-copper-cobalt nanoalloys as robust multifunctional non-platinum electrocatalysts for fuel cells
}

\author{
Chaozhong Li (10) ${ }^{1,2}$, Qiang Yuan (10) 1,2, Bing $\mathrm{Ni}^{2}$, Ting $\mathrm{He}^{2}$, Siming Zhang ${ }^{2}$, Yong Long ${ }^{2}$, Lin Gu (1) ${ }^{3} \&$ Xun Wang ${ }^{2}$
}

Recently, the development of high-performance non-platinum electrocatalysts for fuel cell applications has been gaining attention. Palladium-based nanoalloys are considered as promising candidates to substitute platinum catalysts for cathodic and anodic reactions in fuel cells. Here, we develop a facile route to synthesize dendritic palladium-copper-cobalt trimetallic nanoalloys as robust multifunctional electrocatalysts for oxygen reduction and formic acid oxidation. To the best of our knowledge, the mass activities of the dendritic $\mathrm{Pd}_{59} \mathrm{Cu}_{30} \mathrm{CO}_{11}$ nanoalloy toward oxygen reduction and formic acid oxidation are higher than those previously reported for non-platinum metal nanocatalysts. The $\mathrm{Pd}_{59} \mathrm{Cu}_{30} \mathrm{Co}_{11}$ nanoalloys also exhibit superior durability for oxygen reduction and formic acid oxidation as well as good antimethanol/ethanol interference ability compared to a commercial platinum/carbon catalyst. The high performance of the dendritic $\mathrm{Pd}_{59} \mathrm{Cu}_{30} \mathrm{Co}_{11}$ nanoalloys is attributed to a combination of effects, including defects, a synergistic effect, change of $d$-band center of palladium, and surface strain.

\footnotetext{
${ }^{1}$ College of Chemistry and Chemical Engineering, Guizhou University, Guiyang, Guizhou Province 550025, China. ${ }^{2}$ Key Lab of Organic Optoelectronics and Molecular Engineering, Department of Chemistry, Tsinghua University, Beijing 100084, China. ${ }^{3}$ Chinese Academy of Sciences and Beijing National Laboratory for Condensed Matter Physics, Beijing 100190, China. Correspondence and requests for materials should be addressed to

Q.Y.(email: qyuan@gzu.edu.cn) or to X.W.(email: wangxun@mail.tsinghua.edu.cn)
} 
F uel cells (FCs) are efficient, clean, and sustainable energy generation units that produce electricity from fuels such as hydrogen, formic acid, methanol, and ethanol ${ }^{1-3}$. Platinum (Pt) is widely applied as a catalyst for anode and cathode reactions in $\mathrm{FCs}^{4-8}$, but many factors, including high cost that accounts for over $55 \%$ of the total $\operatorname{cost}^{9}$, scarcity, poor durability, and sluggish reaction kinetics of the oxygen reduction reaction (ORR), tremendously impede the commercial application of FCs. Therefore, developing highly effective non-Pt alloy catalysts for FCs has aroused great interest and concern of researchers from all over the world since such alloys can enhance the catalytic performance through optimizing the binding energy between reactants, intermediates and products with the alloy surface at the nanoscale ${ }^{10-13}$. For instance, Linic's group, Yoo's group, and Yang's group, respectively reported Ag-Co alloy, Rh-Sn alloy, $\mathrm{Pd}-\mathrm{Rh}$ alloy, and $\mathrm{Au}-\mathrm{Rh}$ alloy catalysts for electrochemical ORR in basic media ${ }^{14-18}$. However, most of the mass activities reported on non-Pt metal catalysts are below $0.20 \mathrm{~A} \mathrm{mg}^{-1}$ for ORR, which is still far from the target $\left(0.44 \mathrm{~A} \mathrm{mg}^{-1}{ }_{\mathrm{Pt}}\right.$ at $0.9 \mathrm{~V}$ reversible hydrogen electrode (RHE)) of the U.S. Department of Energy ${ }^{19}$. Besides activities, the alcohol (methanol or ethanol) tolerance of metal catalysts is an important concern for direct alcohol (methanol or ethanol) FCs since these fuel molecules generally penetrate the polymer electrolyte membrane and diffuse from the anode to the cathode, which will greatly lower the performance and efficiency of metal catalysts. However, no alcohol tolerance experiments were mentioned on aforementioned non-Pt metal catalysts.

Among non-Pt multimetallic electrocatalysts, Pd-based electrocataysts have received ample attention for organic molecular oxidation and ORR ${ }^{20-39}$. Previous reports have shown that Pdbased nanoalloys can exhibit superior catalytic performance relative to Pt catalysts for FC applications ${ }^{40-43}$. As we know, the size, composition and complex shape (e.g., a dendritic shape) can be used to tune the electrocatalytic performance of Pd-based catalysts. Furthermore, many parameters, such as Pd-Pd interatomic distance, the number of Pd nearest neighbors, the $d$-band center of Pd and the Pd content on the nanoalloy surface, will change when Pd alloys with $3 d$ transition metals ${ }^{10,12,13}$. Therefore, rational regulation of these parameters can boost the catalytic activity and/or durability of Pd-based nanocatalysts for ORR and/or small organic molecular oxidation. For instance, Han's group $^{40}$ and Huang's group ${ }^{43}$ have, respectively, displayed $\mathrm{PdCuCo}$ anisotropic structure and ordered spherical $\mathrm{PdCuCo}$ with mass activities at $0.9 \mathrm{~V}$ versus RHE of 0.18 and $0.13 \mathrm{~A} \mathrm{mg}$ ${ }^{-1}{ }_{\mathrm{Pd}}$ for ORR, but no alcohol tolerance experiments were mentioned. Xing's group has reported that the mass activity (MA) of palladium-cobalt phosphorus/carbon $(\mathrm{Pd}-\mathrm{CoP} / \mathrm{C})$ is $2.757 \mathrm{~A}$ $\mathrm{mg}^{-1}{ }_{\mathrm{Pd}}$ toward formic acid oxidation (FAO) ${ }^{21}$. Zhang's group has reported that $4 \mathrm{H} /$ face-centered cubic (fcc) Au@Pd core-shell nanorods exhibit high activity toward ethanol oxidation $(\mathrm{EO})^{24}$. However, to the best of our knowledge, there is no report on the synthesis of trimetallic PdCuCo dendritic nanoalloys as robust multifunctional electrocatalysts for both ORR and FAO.

Herein, we report a facile synthesis of trimetallic PdCuCo dendritic nanoalloys with abundant defects. The electrocatalytic performance of these as-synthesized dendritic PdCuCo nanoalloys toward ORR and FAO has been investigated. Compared with commercial $\mathrm{Pt} / \mathrm{C}$ or $\mathrm{Pd}$ black, the dendritic $\mathrm{Pd}_{59} \mathrm{Cu}_{30} \mathrm{Co}_{11}$ nanoalloys demonstrate much higher MA and durability. Besides, the dendritic $\mathrm{Pd}_{59} \mathrm{Cu}_{30} \mathrm{Co}_{11}$ nanoalloys also exhibit high alcohol (methanol or ethanol) tolerance compared with commercial Pt/C. Thus, this approach provides an effective route for fabricating dentritic PdCuCo nanoalloys as robust multifunctional electrocatalysts for ORR and FAO by creating abundant defects.

\section{Results}

Structural characterization. Figure la, b and Supplementary Fig. 1a showed the representative transmission electron microscopy (TEM) images of the as-synthesized $\mathrm{Pd}_{59} \mathrm{Cu}_{30} \mathrm{Co}_{11}$ nanocrystals (the composition was determined by the inductively coupled plasma optical emission spectrometry (ICP-OES), Supplementary Table 1). As can be seen, the obtained products were of uniform size of 66.25 $\pm 4.5 \mathrm{~nm}$ (Supplementary Fig. 1b) and displayed dendritic shapes. These dendritic particles were assembled with dozens of small grains, and the size of most small grains was sub- $5.0 \mathrm{~nm}$, around $4.28 \mathrm{~nm}$ (Supplementary Fig. 1c). Well-resolved lattice fringes (Fig. 1c) are observed in the sub-5.0 $\mathrm{nm}$ grains and the lattice distance of 0.217 $\mathrm{nm}$ is very closed to the (111) interplanar distance of face-centered cubic $(f c c)$ Pd. The energy dispersive X-ray spectroscopy data of one single dendritic particle showed that the as-synthesized dendritic particle consists of Pd, $\mathrm{Cu}$, and Co (Supplementary Fig. 1d). The Xray diffraction (XRD) patterns (Supplementary Fig. 1e) of the assynthesized $\mathrm{Pd}_{59} \mathrm{Cu}_{30} \mathrm{Co}_{11}$ nanocrystals showed four peaks located at $40.45,47.05,68.70$, and $81.85^{\circ} 2 \theta$ that can be indexed to (111), (200), (220), and (311) planes of the $f c c$ Pd (JCPDS-46-1403) ${ }^{44}$, respectively. The diffraction pattern is not characteristic of $f c c \mathrm{Cu}$ (JCPDS-04$0836)^{23}$ and $f c c$ Co (JCPDS- $\left.15-0806\right)^{45}$ phases. The peak positions of $\mathrm{Pd}_{50} \mathrm{Cu}_{50}, \mathrm{Pd}_{88} \mathrm{Co}_{12}$, and $\mathrm{Pd}_{59} \mathrm{Cu}_{30} \mathrm{Co}_{11}$ are shifted to higher angles relative to those of the pure Pd crystal (JCPDS-46-1403), indicating that the smaller $\mathrm{Cu}$ and $\mathrm{Co}$ atoms are incorporated into the $\mathrm{Pd}$ lattice. According to the XRD patterns and the Debye-Scherrer equation ${ }^{46}$ (Table 1), $\mathrm{Cu}$ and/or Co entering the Pd lattice can induce lattice contraction and strain variation, and the strain variations of trimetallic $\mathrm{PdCuCo}$ nanoalloys $\left(\mathrm{Pd}_{59} \mathrm{Cu}_{30} \mathrm{Co}_{11}: 3.50 \%\right.$; $\left.\mathrm{Pd}_{56} \mathrm{Cu}_{38} \mathrm{Co}_{6}: 2.56 \% ; \mathrm{Pd}_{62} \mathrm{Cu}_{16} \mathrm{Co}_{22}: 2.11 \%\right)$ are higher than that of bimetallic $\mathrm{Pd}_{50} \mathrm{Cu}_{50}(1.62 \%)$ and $\mathrm{Pd}_{88} \mathrm{Co}_{12}(0.72 \%)$, which indicates that simultaneously introducing $\mathrm{Cu}$ and $\mathrm{Co}$ atoms should result in greater strain variation than introducing only $\mathrm{Cu}$ or $\mathrm{Co}$ in current system and would enhance catalytic performance of nanocrystals $12,13,39,40,43$. The results of XRD indicated the formation of $\mathrm{Pd}, \mathrm{Cu}$, and Co nanoalloys. Moreover, the nanoalloy structure of the as-synthesized $\mathrm{Pd}_{59} \mathrm{Cu}_{30} \mathrm{Co}_{11}$ nanodendrites was further confirmed by aberration-corrected high-resolution elemental mapping analysis (Fig. 1d-h). The elemental mapping of $\mathrm{Pd}_{59} \mathrm{Cu}_{30} \mathrm{Co}_{11}$, showed that the $\mathrm{Pd}, \mathrm{Cu}$, and $\mathrm{Co}$ distributed throughout the whole particle (Fig. 1e-h). Simultaneously, the $\mathrm{Pd}, \mathrm{Cu}$, and $\mathrm{Co}$ atoms were verified to coexist in the topmost atomic layer within near-surface of the as-synthesized $\mathrm{Pd}_{59} \mathrm{Cu}_{30} \mathrm{Co}_{11}$ nanodendrite and $\mathrm{Pd}$ atoms neighbored $\mathrm{Cu}$ and $\mathrm{Co}$ atoms. The aberration-corrected high-resolution TEM was further used to analyze the surface structure of the as-synthesized $\mathrm{Pd}_{59} \mathrm{Cu}_{30} \mathrm{Co}_{11}$ nanodendrite. As shown in Fig. 2, abundant defects including low-coordination number (edges, corners, and steps) atoms, grain boundaries, lattice disorder, gap atoms, vacancies, and nanotwins were clearly observed in the surface. These defects have been confirmed to act as highly active sites and can boost the catalytic performance of catalysts in catalytic reaction $^{4,19,47-51}$.

X-ray photoelectron spectroscopy (XPS) is generally accepted to analyze the surface composition and state of nanocrystal surface within $2.0 \mathrm{~nm}$. The XPS results (Fig. 3) of the assynthesized $\mathrm{Pd}_{59} \mathrm{Cu}_{30} \mathrm{Co}_{11}$ showed that the $\mathrm{Pd}, \mathrm{Cu}$, and $\mathrm{Co}$ atoms coexisted in the near-surface of $\mathrm{Pd}_{59} \mathrm{Cu}_{30} \mathrm{Co}_{11}$ nanoalloys. The binding energy of the Pd $3 d$ peaks (Fig. 3a) shifted to 335.5 and $340.7 \mathrm{eV}$ compared to the standard Pd $3 d$ peaks (335.2 and 340.4 $\mathrm{eV}$ ), and the binding energy of metallic Pd in the nanosurface of $\mathrm{Pd}_{59} \mathrm{Cu}_{30} \mathrm{Co}_{11}$ nanoalloys positively shifted about $0.3 \mathrm{eV}$, which meant the downshift of the $d$-band center of Pd and this result was in accordance with aforementioned reports ${ }^{13,46,52,53}$. To further probe the local structure of the $\mathrm{Pd}_{59} \mathrm{Cu}_{30} \mathrm{Co}_{11}$ nanoalloys at atomic scale, the X-ray absorption fine structure measurements were performed at the Pd K-edge. From the X-ray absorption 

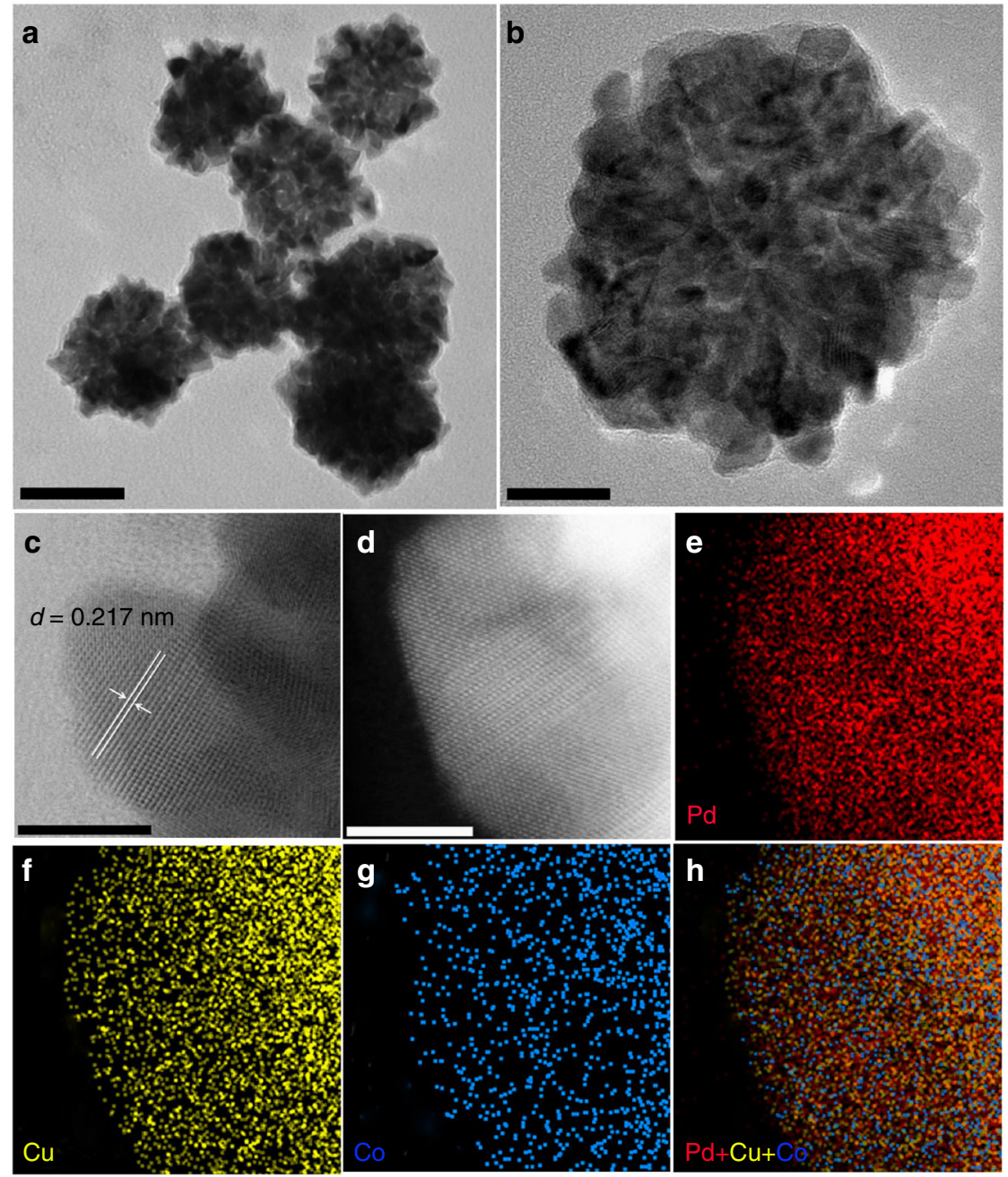

Fig. 1 Characterization of the as-synthesized $\mathrm{Pd}_{59} \mathrm{Cu}_{30} \mathrm{Co}_{11}$ nanoalloys. The typical transmission electron microscopy (TEM) (a, b), the high-resolution TEM (HRTEM) (c) images, the aberration-corrected high-resolution high-angle annular-dark field scanning transmission electron microscopy (HAADF-STEM) (d) images and the corresponding energy dispersive $\mathrm{X}$-ray spectroscopy (EDS) elemental mapping (e-h) images of the as-synthesized $\mathrm{Pd}_{59} \mathrm{Cu}_{30} \mathrm{Co}_{11}$ nanoalloys. (Scale bar: $\mathbf{a}$ is $50 \mathrm{~nm}, \mathbf{b}$ is $20 \mathrm{~nm}, \mathbf{c}, \mathbf{d}$ are $5 \mathrm{~nm}$.)

near edge structure of the Pd K-edge (Fig. 3d), we can clearly see that the Pd K-edge curve of the $\mathrm{Pd}_{59} \mathrm{Cu}_{30} \mathrm{Co}_{11}$ nanoalloys was almost the same as that of metal state of Pd-foil and was quite different from that of the PdO, indicating that the as-synthesized $\mathrm{Pd}_{59} \mathrm{Cu}_{30} \mathrm{Co}_{11}$ did not contain the PdO. The binding energy of $\mathrm{Cu}$ $2 p$ peaks (Fig. $3 \mathrm{~b}$ ) negatively shifted to 931.9 and $951.9 \mathrm{eV}$ compared to the standard $\mathrm{Cu} 2 p$ peaks $(932.6$ and $952.56 \mathrm{eV}$ ). The binding energy of Co $2 p$ peaks (Fig. 3c) showed a positive shift compared with the standard metallic Co peaks (778.3 and $793.2 \mathrm{eV}$ ), and the oxidized state Co also existed in the nanosurface of $\mathrm{Pd}_{59} \mathrm{Cu}_{30} \mathrm{Co}_{11}$ nanoalloys. The shifts of binding energy could be ascribed to the strong electronic effects between $\mathrm{Pd}, \mathrm{Cu}$, and $\mathrm{Co}$ elements through $d$-band hybridization upon alloying within the atomic range ${ }^{12,13,40,41}$.

ORR performance. The ORR performance of the dendritic $\mathrm{Pd}_{59} \mathrm{Cu}_{30} \mathrm{Co}_{11}$ nanoalloys have been investigated compared with commercial Pt/C, bimetallic $\mathrm{Pd}_{50} \mathrm{Cu}_{50}$ and $\mathrm{Pd}_{88} \mathrm{Co}_{12}$ and trimetallic $\mathrm{Pd}_{56} \mathrm{Cu}_{38} \mathrm{Co}_{6}$ and $\mathrm{Pd}_{62} \mathrm{Cu}_{16} \mathrm{Co}_{22}$ alloy nanodendrites (Supplementary Fig. 2, Supplementary Fig. 3, Supplementary Fig. 4, Supplementary Fig. 5, and Supplementary Table 1) obtained at the same synthetic method as the dendritic $\mathrm{Pd}_{59} \mathrm{Cu}_{30} \mathrm{Co}_{11}$ nanoalloys in an $\mathrm{O}_{2}$-saturated $0.1 \mathrm{~mol} \mathrm{~L}^{-1}(\mathrm{M}) \mathrm{KOH}$ solution with a scan rate of $10 \mathrm{mV} \mathrm{s}^{-1}$ and a rotation rate of $1600 \mathrm{pm}$ at room temperature. The ORR polarization curves of these samples are shown in Fig. 4a. The half-wave potentials of the $\mathrm{Pd}_{50} \mathrm{Cu}_{50}$, $\mathrm{Pd}_{88} \mathrm{Co}_{12}, \mathrm{Pd}_{59} \mathrm{Cu}_{30} \mathrm{Co}_{11}, \mathrm{Pd}_{56} \mathrm{Cu}_{38} \mathrm{Co}_{6}, \mathrm{Pd}_{62} \mathrm{Cu}_{16} \mathrm{Co}_{22}$, and commercial Pt/C catalysts are $0.86,0.90,0.91,0.90,0.89$, and $0.87 \mathrm{~V}$, respectively, which exhibited that the $\mathrm{Pd}_{59} \mathrm{Cu}_{30} \mathrm{Co}_{11}$ nanoalloys had a greatly reduced ORR overpotential and indicated the superior activity. This was also confirmed by Tafel plots of these samples (Fig. 4a, inset). The positions of hydrogen adsorption/ desorption peaks were often used to analyze the surface structure of electrocatalyst (Supplementary Fig. 6a). As can been seen, the hydrogen adsorption/desorption peaks on these samples located at different positon, which meant the surface structure and active site of these electrocatalysts were quite different and would display different ORR performance. The electrochemically active surface area (ECSA), calculated from the results of CO-stripping (Supplementary Fig. 7) of $\mathrm{Pd}_{50} \mathrm{Cu}_{50}, \mathrm{Pd}_{88} \mathrm{Co}_{12}, \mathrm{Pd}_{59} \mathrm{Cu}_{30} \mathrm{Co}_{11}$, $\mathrm{Pd}_{56} \mathrm{Cu}_{38} \mathrm{Co}_{6}$, and $\mathrm{Pd}_{62} \mathrm{Cu}_{16} \mathrm{Co}_{22}$ dendritic nanoalloys was around $37.9,41.2,58.7,46.3$, and $44.7 \mathrm{~m}^{2} \mathrm{~g}^{-1} \mathrm{Pd}_{\mathrm{Pd}}$, respectively. The ECSA of commercial Pt/C was $67.8 \mathrm{~m}^{2} \mathrm{~g}^{-1} \mathrm{Pt}$. Figure $4 \mathrm{~b}$ showed the specific activity (SA) and MA of ORR normalized by ECSA and Pd or Pt loading at $0.9 \mathrm{~V}$ versus a RHE using Koutecky-Levich equation, respectively. Among them, the $\mathrm{Pd}_{59} \mathrm{Cu}_{30} \mathrm{Co}_{11}$ nanoalloys showed the best SA and MA. The SA and MA on the $\mathrm{Pd}_{59} \mathrm{Cu}_{30} \mathrm{Co}_{11}$ nanoalloys were $0.90 \mathrm{~mA} \mathrm{~cm}^{-2}$ and $0.38 \mathrm{~A} \mathrm{mg}^{-1}$ Pd, respectively. 


\begin{tabular}{|c|c|c|c|}
\hline Samples & $\begin{array}{l}2 \theta / \text { degree } \\
\text { (111) }\end{array}$ & $\begin{array}{l}\text { Lattice parameter } \\
(1 / \AA)\end{array}$ & Strain (\%) \\
\hline $\begin{array}{l}\text { Pd crystal (JCPDS-46- } \\
1403)^{23}\end{array}$ & 40.11 & 0.2226 & - \\
\hline $\mathrm{Pd}_{50} \mathrm{Cu}_{50}$ & 41.68 & 0.2262 & 1.62 \\
\hline $\mathrm{Pd}_{88} \mathrm{Co}_{12}$ & 40.15 & 0.2242 & 0.72 \\
\hline $\mathrm{Pd}_{56} \mathrm{Cu}_{38} \mathrm{Co}_{6}$ & 40.49 & 0.2283 & 2.56 \\
\hline $\mathrm{Pd}_{59} \mathrm{Cu}_{30} \mathrm{Co}_{11}$ & 40.21 & 0.2304 & 3.50 \\
\hline $\mathrm{Pd}_{62} \mathrm{Cu}_{16} \mathrm{Co}_{22}$ & 40.19 & 0.2273 & 2.11 \\
\hline
\end{tabular}

The MA on $\mathrm{Pd}_{59} \mathrm{Cu}_{30} \mathrm{Co}_{11}$ nanoalloys was 3.45 times higher than commercial $\mathrm{Pt} / \mathrm{C}$ catalysts $\left(0.11 \mathrm{~A} \mathrm{mg}^{-1} \mathrm{Pt}\right)$. Impressively, our $\mathrm{Pd}_{59} \mathrm{Cu}_{30} \mathrm{Co}_{11}$ nanoalloys had a competitively high $\mathrm{MA}$ in comparison with previously reported non-Pt metal nanocatalysts (Supplementary Table 2) that is also superior to the recently reported $\mathrm{PdCuCo}$ anisotropic structure $\left(0.18 \mathrm{~A} \mathrm{mg}^{-1} \mathrm{Pd}^{40}\right.$ and spherical PdCuCo $\left(0.13 \mathrm{~A} \mathrm{mg}^{-1}{ }_{\mathrm{Pd}}\right)^{43}$. Furthermore, at 0.875 and $0.8 \mathrm{~V}$ versus RHE (Fig. $4 \mathrm{c}, \mathrm{d}$ ), the $\mathrm{Pd}_{59} \mathrm{Cu}_{30} \mathrm{Co}_{11}$ nanoalloys exhibited the largest ORR SA $\left(1.73 \mathrm{~mA} \mathrm{~cm}^{-2}\right.$ at $0.875 \mathrm{~V}$, 3.76 times that of commercial $\mathrm{Pt} / \mathrm{C} ; 10.20 \mathrm{~mA} \mathrm{~cm}^{-2}$ at $0.8 \mathrm{~V}$, 3.98 times that of commercial $\mathrm{Pt} / \mathrm{C})$ and $\mathrm{MA}\left(1.01 \mathrm{~A} \mathrm{mg}^{-1} \mathrm{Pd}\right.$ at $0.875 \mathrm{~V}, 3.48$ times that of commercial Pt/C; $5.98 \mathrm{~A} \mathrm{mg}^{-1}{ }_{\mathrm{Pd}}$ at $0.8 \mathrm{~V}, 3.71$ times that of commercial $\mathrm{Pt} / \mathrm{C}$ ). Furthermore, in order to determine the electron transfer number on $\mathrm{Pd}_{59} \mathrm{Cu}_{30} \mathrm{Co}_{11}$ nanoalloys, the ORR polarization curves of $\mathrm{Pd}_{59} \mathrm{Cu}_{30} \mathrm{Co}_{11}$ nanoalloys were investigated by rotating disk electrode (RDE) measurements at different rotation rates from 400 to $2500 \mathrm{rpm}$ in $0.1 \mathrm{M} \mathrm{KOH}$ solution (Supplementary Fig. 8a). The Koutecky-Levich (K-L) plots for $\mathrm{Pd}_{59} \mathrm{Cu}_{30} \mathrm{Co}_{11}$ nanoalloys calculated at different potentials from 0.4 to $0.8 \mathrm{~V}$ were shown in Supplementary Fig. $8 \mathrm{~b}$. The slopes were parallel at different potentials, showing the first-order reaction kinetics and the electron transfer number was around four that indicated fully electrocatalytic reduction of oxygen into water on the $\mathrm{Pd}_{59} \mathrm{Cu}_{30} \mathrm{Co}_{11}$ nanoalloys. The alcohol (methanol or ethanol) tolerance of the dendritic $\mathrm{Pd}_{59} \mathrm{Cu}_{30} \mathrm{Co}_{11}$ nanoalloys was also investigated for ORR. Before testing ORR, the electrocatalytic activity toward methanol or ethanol of the dendritic $\mathrm{Pd}_{59} \mathrm{Cu}_{30} \mathrm{Co}_{11}$ nanoalloys and commercial $\mathrm{Pt} / \mathrm{C}$ were performed using cyclic voltammetry in $0.1 \mathrm{M} \mathrm{KOH}+0.1 \mathrm{M}$ methanol/ ethanol solution. As shown in Fig. 5a-c, typical methanol and EO peaks were observed at 0.88 and $0.87 \mathrm{~V}$, respectively, on commercial $\mathrm{Pt} / \mathrm{C}$, while methanol oxidation peak was hardly generated on the dendritic $\mathrm{Pd}_{59} \mathrm{Cu}_{30} \mathrm{Co}_{11}$ nanoalloys and $\mathrm{EO}$ peak was only one-sixth of that on commercial $\mathrm{Pt} / \mathrm{C}$, which meant much lower electrocatalytic activity toward methanol and EO on the dendritic $\mathrm{Pd}_{59} \mathrm{Cu}_{30} \mathrm{Co}_{11}$ nanoalloys compared with commercial $\mathrm{Pt} / \mathrm{C}$. The ORR polarization curves (Fig. 5b-d) showed the commercial $\mathrm{Pt} / \mathrm{C}$ had a weak methanol and ethanol tolerance capacity. The half-wave potentials of the commercial $\mathrm{Pt} / \mathrm{C}$ are 0.707 and $0.619 \mathrm{~V}$ versus RHE in the presence of methanol and ethanol, respectively, and the half-wave potentials negatively shifted 0.163 and $0.251 \mathrm{~V}$, respectively, compared with that $(0.87 \mathrm{~V}$ versus RHE; Fig. 4a) without methanol and ethanol. However, the dendritic $\mathrm{Pd}_{59} \mathrm{Cu}_{30} \mathrm{Co}_{11}$ nanoalloys exhibited excellent methanol and ethanol tolerance capacity. The half-wave potential $(0.91 \mathrm{~V}$ without methanol and ethanol; Fig. 4a) were barely affected by methanol $(0.909 \mathrm{~V}$ versus RHE) and ethanol $(0.907 \mathrm{~V}$ versus RHE). These results showed that the dendritic $\mathrm{Pd}_{59} \mathrm{Cu}_{30} \mathrm{Co}_{11}$ nanoalloys had much better antimethanol and ethanol interference ability than the commercial $\mathrm{Pt} / \mathrm{C}$.

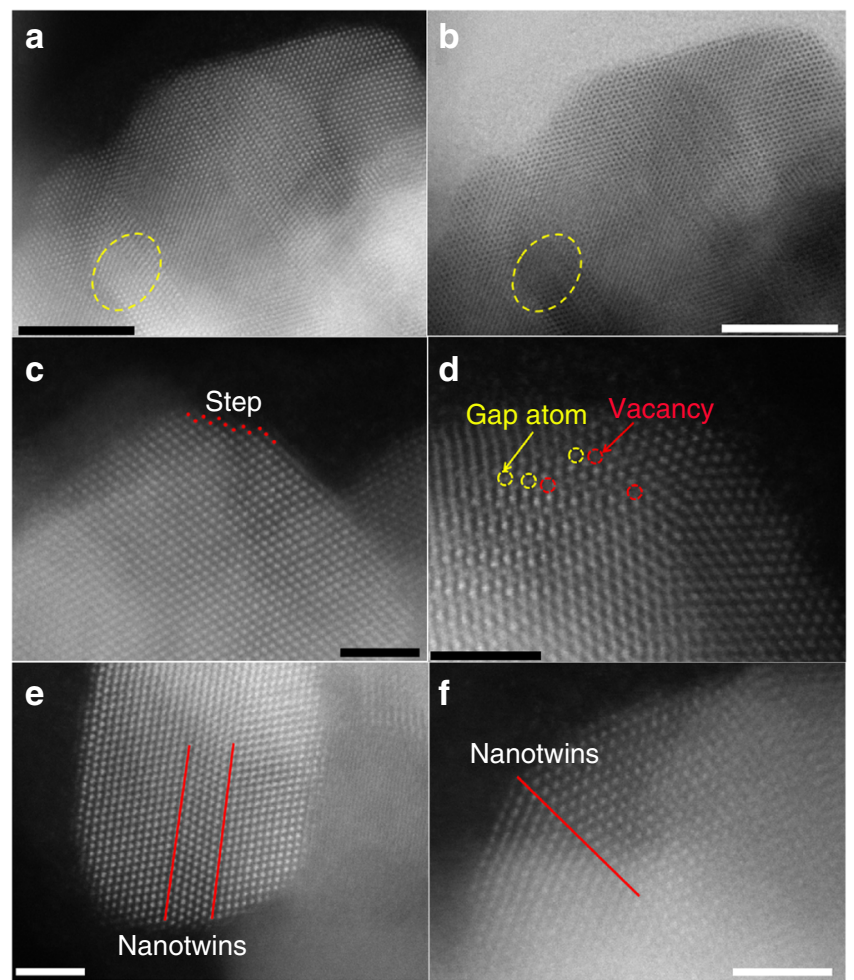

Fig. 2 Surface defect characterization of the as-synthesized $\mathrm{Pd}_{59} \mathrm{Cu}_{30} \mathrm{Co}_{11}$ nanoalloys. Defect analysis images of the as-synthesized dendritic $\mathrm{Pd}_{59} \mathrm{Cu}_{30} \mathrm{Co}_{11}$ nanoalloys through aberration-corrected transmission electron microscopy (TEM). a, b Edge, corner and lattice disorder (in yellow dashed circle); c step; $\mathbf{d}$ gap atom in yellow dashed circle and vacancy in red dashed circle; e, f Nanotwins. (Scale bar: a, b are $5 \mathrm{~nm}, \mathbf{c}-\mathbf{f}$ are $2 \mathrm{~nm}$.)

The dendritic $\mathrm{Pd}_{59} \mathrm{Cu}_{30} \mathrm{Co}_{11}$ nanoalloys also presented longterm durability under the ORR reaction condition. The accelerated durability tests (ADTs) were used to evaluate ORR durability under a sweep rate of $100 \mathrm{mV} \mathrm{s}^{-1}$ between 0.53 and $1.03 \mathrm{~V}$ in $\mathrm{O}_{2}$-saturated $0.1 \mathrm{M} \mathrm{KOH}$ solution. After $5000,10,000$, and 15,000 sweeping cycles, the $\mathrm{MA}$ of the $\mathrm{Pd}_{59} \mathrm{Cu}_{30} \mathrm{Co}_{11}$ nanoalloy was $0.44,0.40$, and $0.26 \mathrm{~A} \mathrm{mg}^{-1} \mathrm{Pd}$, respectively, at $0.9 \mathrm{~V}$ versus RHE (Fig. $4 \mathrm{e}-\mathrm{f}$ ), which first experienced a rise and then a drop. This could be ascribed to the surface structure change under the ADTs and the same phenomenon was also observed about trimetallic PtPdAu alloys reported by Ding's group $^{54}$. However, the MA of Pt/C after 5000 and 10,000 sweeping cycles was 0.05 and $0.03 \mathrm{~A} \mathrm{mg}^{-1}$, respectively, at $0.9 \mathrm{~V}$ versus RHE. After 10,000 sweeping cycles, the Pt/C catalyst shows the $72.7 \%$ loss of $\mathrm{MA}$, while the $\mathrm{Pd}_{59} \mathrm{Cu}_{30} \mathrm{Co}_{11}$ nanoalloys showed no loss of $\mathrm{MA}\left(0.40 \mathrm{~A} \mathrm{mg}^{-1} \mathrm{Pd}\right)$ that was 13.3 times higher than $\mathrm{Pt} / \mathrm{C}$. And after 15,000 sweeping cycles, the MA $\left(0.26 \mathrm{~A} \mathrm{mg}^{-1}{ }_{\mathrm{Pd}}\right)$ of the $\mathrm{Pd}_{59} \mathrm{Cu}_{30} \mathrm{Co}_{11}$ nanoalloys is 2.36 times higher than initial MA $\left(0.11 \mathrm{~A} \mathrm{mg}^{-1}{ }_{\mathrm{Pt}}\right)$ of $\mathrm{Pt} / \mathrm{C}$ and had a loss of $31.6 \%$ compared with the initial MA $\left(0.38 \mathrm{~A} \mathrm{mg}^{-1} \mathrm{Pd}\right)$. The above results exhibited that the $\mathrm{Pd}_{59} \mathrm{Cu}_{30} \mathrm{Co}_{11}$ nanoalloys had considerable enhancement with respect to durability compared with commercial $\mathrm{Pt} / \mathrm{C}$. After ADTs, we checked the morphologies of the $\mathrm{Pd}_{59} \mathrm{Cu}_{30} \mathrm{Co}_{11}$ nanoalloys using TEM (Supplementary Fig. 9). The TEM images showed the $\mathrm{Pd}_{59} \mathrm{Cu}_{30} \mathrm{Co}_{11}$ nanoalloys also maintained dendritic structure, however, after 15,000 sweeping cycles, the size of the small grains obviously increased due to the movement, aggregation and Ostwald ripening processes under the ADTs ${ }^{19}$, and we can clearly observe that some dendritic nanocrystals are hollowlike shapes, which caused by the electrochemical dealloying of $\mathrm{Cu}$ or Co (Supplementary Fig. 9), these were the reason why the 
a

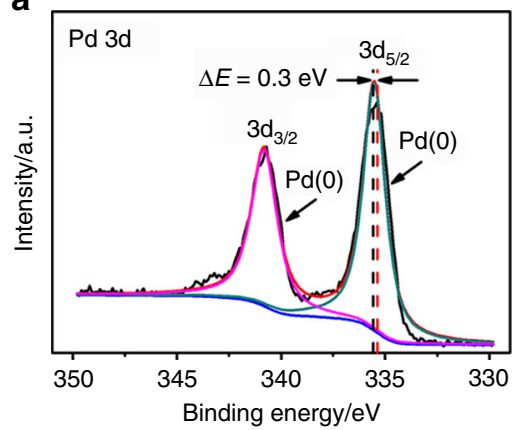

C

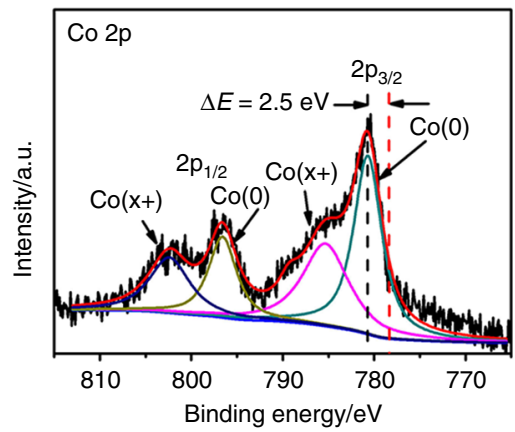

b

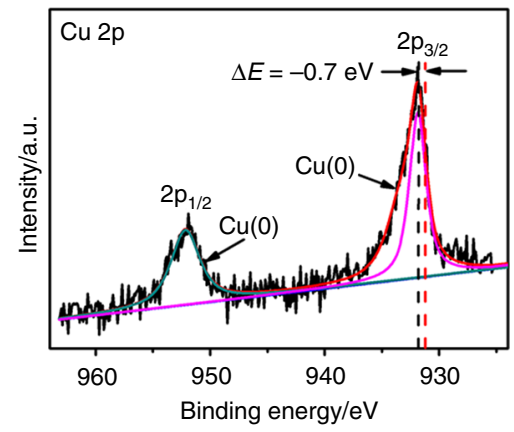

d

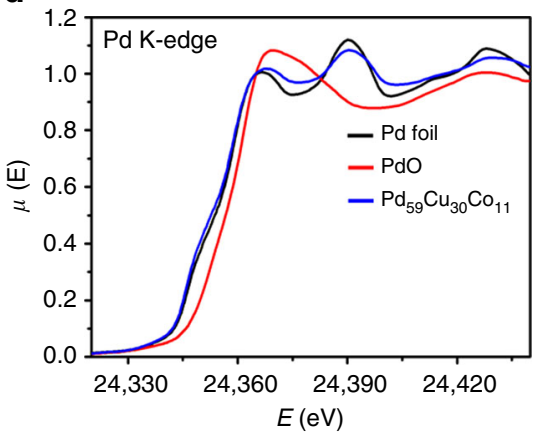

Fig. 3 In-depth composition and structural analyses of the $\mathrm{Pd}_{59} \mathrm{Cu}_{30} \mathrm{Co}_{11}$ nanoalloys. The $\mathrm{X}$-ray photoelectron spectroscopy (XPS) spectra of the assynthesized dendritic $\mathrm{Pd}_{59} \mathrm{Cu}_{30} \mathrm{Co}_{11}$ nanoalloys a $\mathrm{Pd} 3 d$ region, $\mathbf{b} \mathrm{Cu} 2 p$ region, $\mathbf{c} \mathrm{Co} 2 p$ region (the red dash lines in pictures indicate the standard positions of $\mathrm{Pd} 3 d, \mathrm{Cu} 2 p$ and $\mathrm{Co} 2 p$ ), $\mathbf{d}$ the X-ray absorption near edge structure (XANES) spectra for the Pd K-edge

catalytic activity decreased. After ADT cycles, the composition of $\mathrm{Pd}_{59} \mathrm{Cu}_{30} \mathrm{Co}_{11}$ nanoalloys changed (Supplementary Fig. 10). After 5000 cycles, the composition was 69.41 at $\% \mathrm{Pd}, 29.29$ at\% $\mathrm{Cu}$, and 1.30 at\% Co. After 10,000 cycles, the composition was the 77.30 at $\% \mathrm{Pd}, 21.78$ at $\% \mathrm{Cu}$, and 0.92 at $\% \mathrm{Co}$, and after 15,000 cycles it was 83.68 at\% $\mathrm{Pd}, 15.68$ at\% $\mathrm{Cu}$ and 0.64 at\% Co. Moreover, the dendritic structure had stronger antiaggregation capacity due to their free-standing architectural feature than commercial Pt/C. For commercial Pt/C, after 10,000 cycles, the size of $\mathrm{Pt}$ particles obviously increased relative to initial size, namely, the size increased from sub-3.0 nm to around $10 \mathrm{~nm}$ (Supplementary Fig. 11), which led to the sharp fall of activity of commercial Pt/C.

Formic acid oxidation performance. The dendritic $\mathrm{Pd}_{59} \mathrm{Cu}_{30} \mathrm{Co}_{11}$ nanoalloys also exhibited excellent $\mathrm{FAO}$ activity. Figure $6 \mathrm{a}$ showed that the $\mathrm{SA}$ of the $\mathrm{Pd}_{50} \mathrm{Cu}_{50}, \mathrm{Pd}_{88} \mathrm{Co}_{12}$, $\mathrm{Pd}_{56} \mathrm{Cu}_{38} \mathrm{Co}_{6}, \mathrm{Pd}_{59} \mathrm{Cu}_{30} \mathrm{Co}_{11}, \mathrm{Pd}_{62} \mathrm{Cu}_{16} \mathrm{Co}_{22}$, commercial Pd black, and $\mathrm{Pt} / \mathrm{C}$ were around $6.38,2.94,7.25,9.06,6.46,2.24$, and 0.56 $\mathrm{mA} \mathrm{cm}{ }^{-2}$, respectively. The MA (Fig. 6b) of the $\mathrm{Pd}_{50} \mathrm{Cu}_{50}$, $\mathrm{Pd}_{88} \mathrm{Co}_{12}, \mathrm{Pd}_{56} \mathrm{Cu}_{38} \mathrm{Co}_{6}, \mathrm{Pd}_{59} \mathrm{Cu}_{30} \mathrm{Co}_{11}, \mathrm{Pd}_{62} \mathrm{Cu}_{16} \mathrm{Co}_{22}$, commercial $\mathrm{Pd}$ black, and $\mathrm{Pt} / \mathrm{C}$ was $2.42,1.21,3.36,5.32,2.89,0.39 \mathrm{~A} \mathrm{mg}^{-1}{ }_{\mathrm{Pd}}$ and $0.35 \mathrm{~A} \mathrm{mg}^{-1}$, respectively. These values (Fig. $6 \mathrm{c}$ ) showed that the as-synthesized Pd-based alloys displayed greatly enhanced activity compared with commercial Pd black and Pt/C. And the values of $\mathrm{Pd}_{59} \mathrm{Cu}_{30} \mathrm{Co}_{11}$ nanoalloys were the largest. The FAO SA and $\mathrm{MA}$ of the $\mathrm{Pd}_{59} \mathrm{Cu}_{30} \mathrm{Co}_{11}$ nanoalloys were 4.04 and 13.6 times higher than that of commercial Pd black, respectively, and 16.1 and 15.2 times higher than commercial $\mathrm{Pt} / \mathrm{C}$, respectively. Similar to the case of ORR, the $\mathrm{Pd}_{59} \mathrm{Cu}_{30} \mathrm{Co}_{11}$ nanoalloys display high MA relative to previously reported Pd-based electrocatalysts (Supplementary Table 3). Moreover, the stability of the as-synthesized PdCuCo nanoalloys was evaluated by current-time curves and showed better stability than $\mathrm{Pd}_{50} \mathrm{Cu}_{50}, \mathrm{Pd}_{88} \mathrm{Co}_{12}$, commercial $\mathrm{Pd}$ black and Pt/C (Fig. 6d).

\section{Discussion}

The excellent electrocatalytic performance of the as-synthesized dendritic $\mathrm{Pd}_{59} \mathrm{Cu}_{30} \mathrm{Co}_{11}$ nanoalloys is mainly ascribed to the following reasons: (1) The special dendritic nanostructure of the $\mathrm{Pd}_{59} \mathrm{Cu}_{30} \mathrm{Co}_{11}$ nanoalloy can provide abundant defects, such as low-coordination number atoms (edges, corners, and steps), grain boundaries, lattice disorder, nanotwins, gap atoms, and vacancies, which have been confirmed to boost the catalytic performance in catalytic reactions ${ }^{4,19,43,47-51}$. (2) Synergistic surface effects between $\mathrm{Pd}, \mathrm{Cu}$, and $\mathrm{Co}$ elements are present in the topmost atomic layer and favor the removal of poisoning intermediates (such as $\mathrm{CO}$ adsorbed $\left(\mathrm{CO}_{\mathrm{ads}}\right)$ and $\mathrm{OH}$ adsorbed $\left(\mathrm{OH}_{\mathrm{ads}}\right)$ ) that are produced in the electrocatalytic reaction ${ }^{6,23,37,42}$. Moreover, metallic $\mathrm{Cu}$ and $\mathrm{Co}$ have been found to constitute sites for activating oxygen, water or small organic molecules and improve the activity and durability in FCs ${ }^{13,23,54-62}$. (3) Pd alloying with $\mathrm{Cu}$ and Co changes the surface electronic structure through ligand effect and downshifts the $d$-band center of Pd, which can tune the adsorption/desorption capacities of activating reactant molecules or intermediates and enhance the catalytic performance $39,40,43$. (4) Strain effects have also been shown to contribute to high catalytic performance $7,10,12,60-62$. The surface strain in dendritic $\mathrm{Pd}_{59} \mathrm{Cu}_{30} \mathrm{Co}_{11}$ nanoalloys may be attributed to the lattice mismatch triggered by the incorporation of smaller $\mathrm{Cu}$ and $\mathrm{Co}$ atoms into the Pd $f c c$ lattice, small size of sub-5.0 nm grains that construct the dendritic structure and a boundary that originates from the mutual cross-linking of small grains ${ }^{59,60}$.

In conclusion, the defect-rich dendritic PdCuCo nanoalloys have been synthesized by a facile one-pot method to be developed as high-performance non-Pt nanocatalysts toward ORR and FAO. Among them, a $\mathrm{Pd}_{59} \mathrm{Cu}_{30} \mathrm{Co}_{11}$ nanoalloy shows the best catalytic performances. For ORR, the SA $\left(0.90 \mathrm{~mA} \mathrm{~cm}^{-2}\right.$ at $0.9 \mathrm{~V}$ and $1.73 \mathrm{~mA} \mathrm{~cm}^{-2}$ at $0.875 \mathrm{~V}$ versus $\left.\mathrm{RHE}\right)$ and $\mathrm{MA}\left(0.38 \mathrm{~A} \mathrm{mg}^{-1}{ }_{\mathrm{Pd}}\right.$ at $0.9 \mathrm{~V}$ versus RHE and $1.01 \mathrm{~A} \mathrm{mg}^{-1}{ }_{\mathrm{Pd}}$ at $0.875 \mathrm{~V}$ versus RHE) of the dendritic $\mathrm{Pd}_{59} \mathrm{Cu}_{30} \mathrm{Co}_{11}$ nanoalloy are 2.19 and 3.76 times and 
a

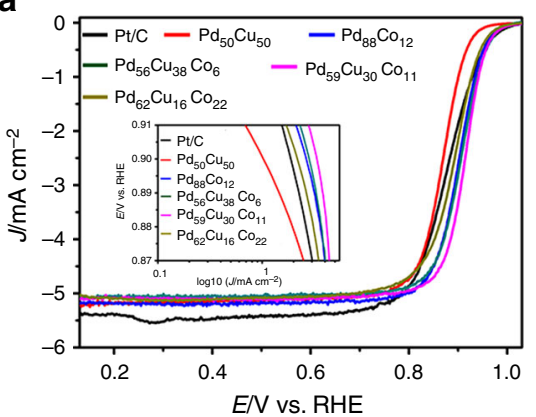

C

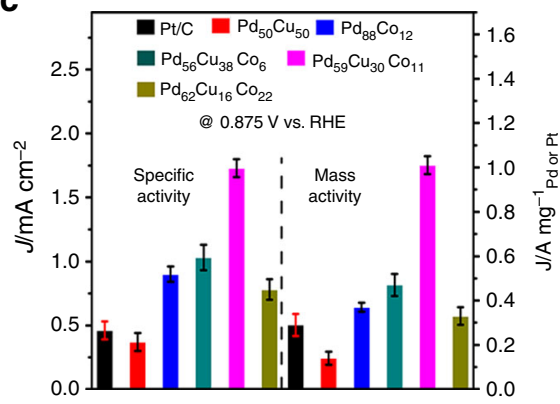

e

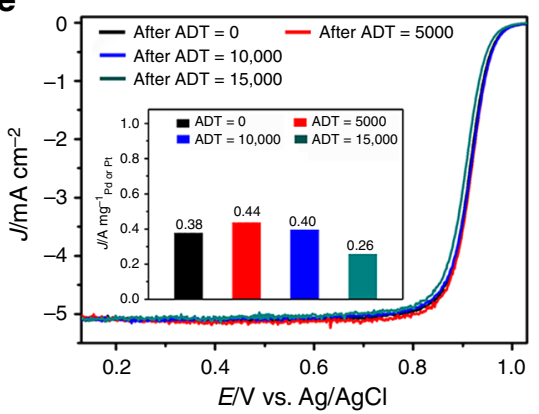

b

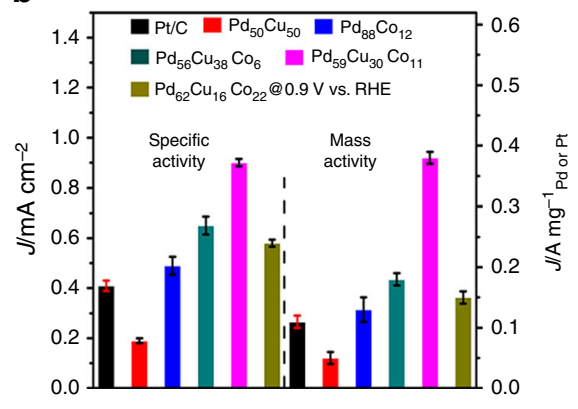

d

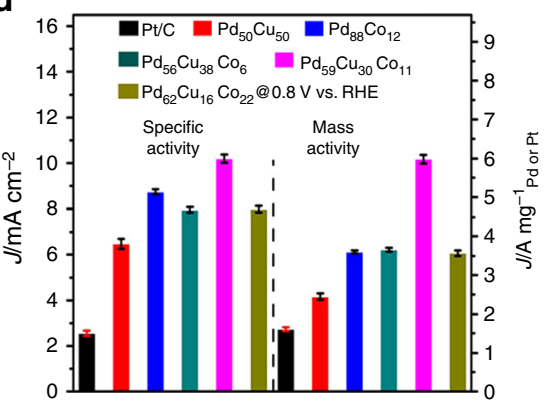

f

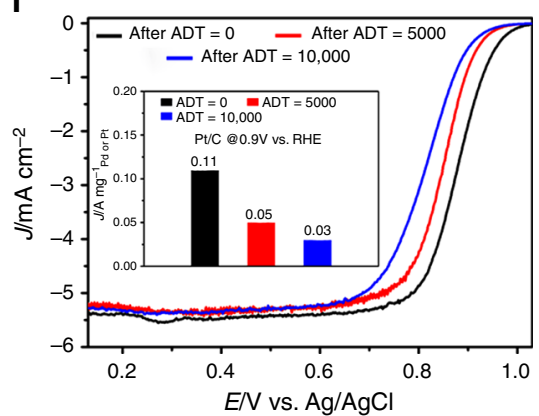

Fig. 4 Oxygen reduction reaction performance characterization. The oxygen reduction reaction (ORR) performance of $\mathrm{Pt} / \mathrm{C}, \mathrm{Pd}_{88} \mathrm{Co}_{12}, \mathrm{Pd}_{50} \mathrm{Cu}_{50}$, $\mathrm{Pd}_{56} \mathrm{Cu}_{38} \mathrm{Co}_{6}, \mathrm{Pd}_{59} \mathrm{Cu}_{30} \mathrm{Co}_{11}$, and $\mathrm{Pd}_{62} \mathrm{Cu}_{16} \mathrm{Co}_{22}$ catalysts. a The ORR polarization curves were recorded in $\mathrm{O}_{2}$-saturated 0.1 mol L ${ }^{-1}(\mathrm{M})$ potassium hydroxide $(\mathrm{KOH})$ and the inset was the corresponding specific activity Tafel plots. Histograms of ORR specific activities and mass activities of the Pt/C, $\mathrm{Pd}_{88} \mathrm{Co}_{12}, \mathrm{Pd}_{50} \mathrm{Cu}_{50}, \mathrm{Pd}_{56} \mathrm{Cu}_{38} \mathrm{Co}_{6}, \mathrm{Pd}_{59} \mathrm{Cu}_{30} \mathrm{Co}_{11}$, and $\mathrm{Pd}_{62} \mathrm{Cu}_{16} \mathrm{Co}_{22}$ catalysts at $0.9 \mathrm{~V}(\mathbf{b}), 0.875 \mathrm{~V}(\mathbf{c}$ ), and $0.8 \mathrm{~V}$ (d) versus reversible hydrogen electrode (RHE). e, $\mathbf{f}$ The ORR polarization curves for the $\mathrm{Pd}_{59} \mathrm{Cu}_{30} \mathrm{Co}_{11}$ and commercial Pt/C catalysts before and after cycles of accelerated durability tests (ADTs) (the inset was the corresponding mass activity at $0.90 \mathrm{~V}$ versus $\mathrm{RHE}$ ). Error bars are \pm s.d.

3.45 and 3.48 times those of commercial $\mathrm{Pt} / \mathrm{C}$, respectively. The long-term durability has been evaluated through an ADT. After 10,000 cycles, the commercial $\mathrm{Pt} / \mathrm{C}$ catalyst shows the $72.7 \%$ loss of MA, while the $\mathrm{Pd}_{59} \mathrm{Cu}_{30} \mathrm{Co}_{11}$ nanoalloy showed no loss of MA. After 15,000 cycles, the MA $\left(0.26 \mathrm{~A} \mathrm{mg}^{-1}{ }_{\mathrm{Pd}}\right)$ of the $\mathrm{Pd}_{59} \mathrm{Cu}_{30} \mathrm{Co}_{11}$ nanoalloy is 2.36 times higher than initial MA $\left(0.11 \mathrm{~A} \mathrm{mg}^{-1}{ }_{\mathrm{Pt}}\right)$ of $\mathrm{Pt} / \mathrm{C}$. For FAO, the SA and MA of the $\mathrm{Pd}_{59} \mathrm{Cu}_{30} \mathrm{Co}_{11}$ nanoalloy is 4.04 and 13.6 times higher, respectively, than commercial $\mathrm{Pd}$ black and 16.1 and 15.2 times higher, respectively, than commercial Pt/C. The current-time curves show that the $\mathrm{Pd}_{59} \mathrm{Cu}_{30} \mathrm{Co}_{11}$ nanoalloy exhibits better stability than commercial $\mathrm{Pd}$ black and $\mathrm{Pt} / \mathrm{C}$. And the dendritic $\mathrm{Pd}_{59} \mathrm{Cu}_{30} \mathrm{Co}_{11}$ nanoalloy has good methanol/ethanol tolerance ability. Thus, this work provides an example of the development of a new type of robust multifunctional, non-Pt catalysts for FCs.

\section{Methods}

Synthesis of dendritic $\mathbf{P d}_{59} \mathbf{C u}_{30} \mathrm{Co}_{11}$ nanoalloys. The dendritic $\mathrm{Pd}_{59} \mathrm{Cu}_{30} \mathrm{Co}_{11}$ nanoalloys were prepared by using precursors of $\mathrm{Na}_{2} \mathrm{PdCl}_{4}, \mathrm{CuCl}_{2}$, and $\mathrm{CoCl}_{2}$. Firstly, the $0.25 \mathrm{~mL}$ of $0.1 \mathrm{M} \mathrm{Na}_{2} \mathrm{PdCl}_{4}, 0.125 \mathrm{~mL}$ of $0.1 \mathrm{M}$ of $0.1 \mathrm{M}$ of $\mathrm{CuCl}_{2}$, and $0.125 \mathrm{~mL}$ of $0.1 \mathrm{M}$ of $\mathrm{CoCl}_{2}$ were added to $8.8 \mathrm{~mL}$ of ethylene glycol containing
0.050 g polyvinyl pyrrolidone (PVP-8000), and stirred for 1-2 min then the yellow clear solution was obtained. Secondly, the $0.2 \mathrm{~mL}$ ammonium hydroxide was added to the above solution, and stirred for $30 \mathrm{~min}$. Then, the resulting clear solution was transferred to a $15-\mathrm{mL}$ Teflon-lined stainless-steel autoclave. The oven was then heated at $150^{\circ} \mathrm{C}$ for $8 \mathrm{~h}$, then the Teflon-lined stainless-steel autoclave was taken out after it was cooled to room temperature. The products were separated several times by centrifugation and washing cycles at $10,000 \mathrm{rpm}$ for $15 \mathrm{~min}$ with ethanol. The $\mathrm{Pd}_{59} \mathrm{Cu}_{30} \mathrm{Co}_{11}$ was redispersed in ethanol. By adjusting the ratio of $\mathrm{Cu}$ or $\mathrm{Co}$ precursors, the $\mathrm{Pd}_{50} \mathrm{Cu}_{50}, \mathrm{Pd}_{88} \mathrm{Co}_{12}, \mathrm{Pd}_{56} \mathrm{Cu}_{38} \mathrm{Co}_{6}$, and $\mathrm{Pd}_{62} \mathrm{Cu}_{16} \mathrm{Co}_{22}$ nanoalloys can be obtained under the same procedure. Further details are provided in the Supplementary Methods.

The ORR electrochemical measurement. For the ORR electrochemical measurement, a glassy carbon RDE (PINE, USA) was used. A $\mathrm{Hg} / \mathrm{HgO}(0.1 \mathrm{M} \mathrm{KOH})$ electrode and Pt black plate were used as reference and counter electrodes, respectively. The ORR was performed in the $\mathrm{O}_{2}$-saturated $0.1 \mathrm{M} \mathrm{KOH}$ solution at room temperature. Then, using a glassy carbon RDE at a rotation rate of $1600 \mathrm{rpm}$, the potential was scanned from 0.13 to $1.03 \mathrm{~V}$ (versus RHE) at a scan rate of 10 $\mathrm{mV} \mathrm{s}^{-1}$ and were corrected for capacitive currents in $\mathrm{N}_{2}$ saturation. The kinetic current $\left(i_{\mathrm{k}}\right)$ can be derived from the experimental data using the well-known Koutecky-Levich equation: $\left(1 / i_{\mathrm{K}}=1 / i-1 / i_{\mathrm{L}}\right)$ at $0.90 \mathrm{~V}$ versus RHE, where $i_{\mathrm{L}}$ and $i$ are the diffusion limiting current and measured current $(0.90 \mathrm{~V}$ versus RHE) at kinetic-diffusion control region, respectively.

The tolerance test: $\mathrm{A} \mathrm{Hg} / \mathrm{HgO}(0.1 \mathrm{M} \mathrm{KOH})$ electrode and Pt black plate were used as reference and counter electrodes, respectively. Then MOR or EOR tested 
a

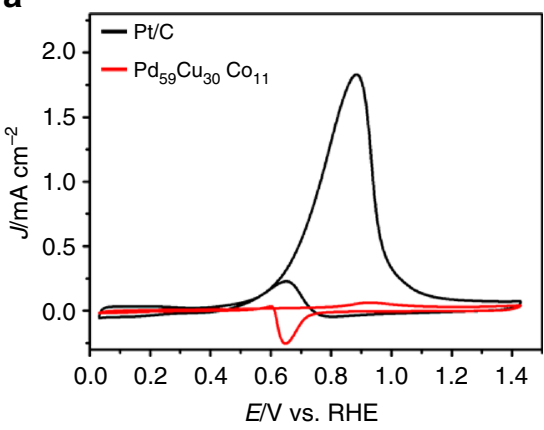

C

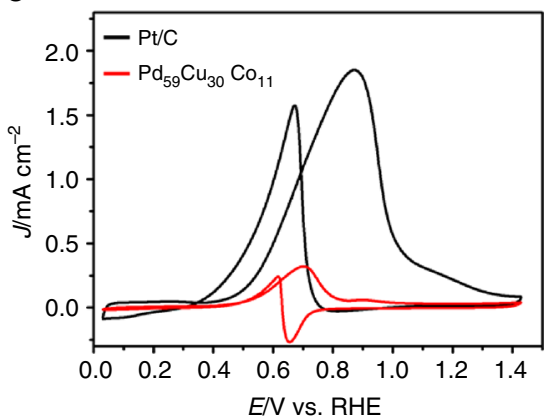

b

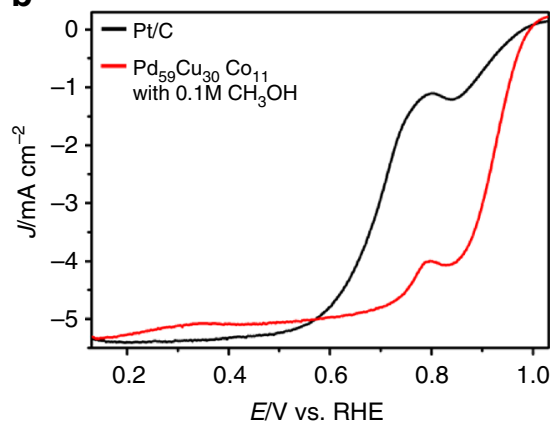

d

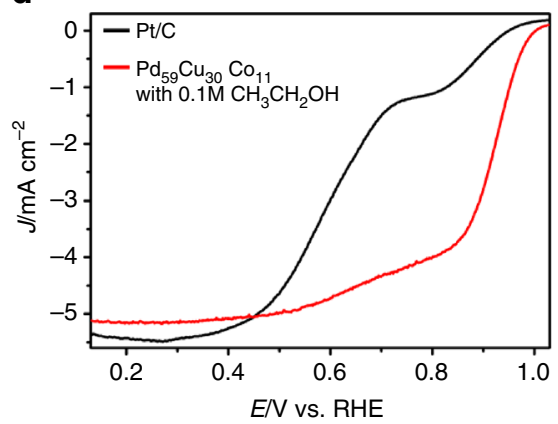

Fig. 5 Methanol and ethanol tolerance tests. Cyclic voltammetry (CV) curves of the dendritic $\mathrm{Pd}_{59} \mathrm{Cu}_{30} \mathrm{Co}_{11}$ nanoalloys and the commercial $\mathrm{Pt} / \mathrm{C}$ in $\mathrm{N}_{2}{ }^{-}$ saturated $0.1 \mathrm{~mol} \mathrm{~L}^{-1}(\mathrm{M})$ potassium hydroxide $(\mathrm{KOH})+0.1 \mathrm{M}$ methanol $\left(\mathrm{CH}_{3} \mathrm{OH}\right)(\mathbf{a})$ or ethanol $\left(\mathrm{CH}_{3} \mathrm{CH}_{2} \mathrm{OH}\right)(\mathbf{c})$ solution at $50 \mathrm{mV} \mathrm{s}{ }^{-1}$. Oxygen reduction reaction (ORR) polarization curves of the dendritic $\mathrm{Pd}_{59} \mathrm{Cu}_{30} \mathrm{Co}_{11}$ nanoalloys and the commercial Pt/C in $\mathrm{O}_{2}$-saturated $0.1 \mathrm{M} \mathrm{KOH}+0.1 \mathrm{M}$ methanol (b) or ethanol (d) solution at $10 \mathrm{mV} \mathrm{s}^{-1}$ and rotation rate of $1600 \mathrm{rpm}$

a

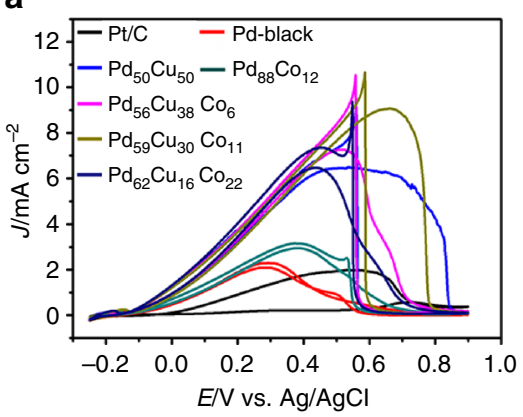

C

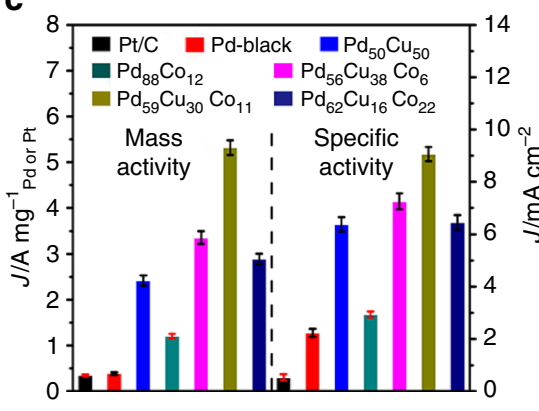

b

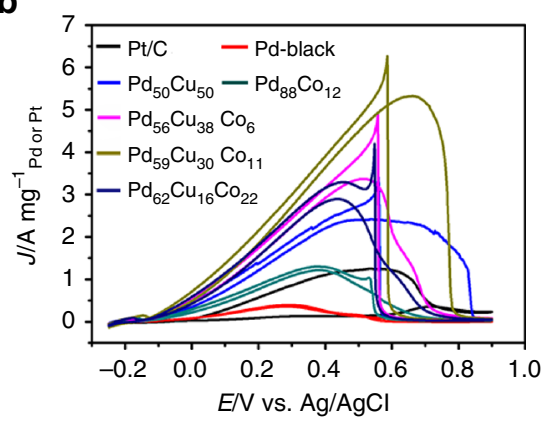

d

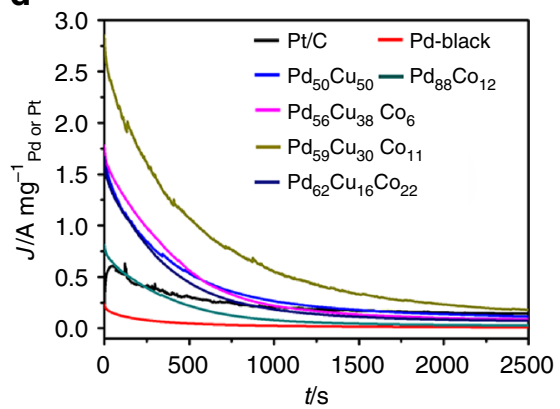

Fig. 6 Formic acid oxidation (FAO) characterization. Cyclic voltammetry (CV) curves (specific activity (a) and mass activity (b)) of the as-synthesized $\mathrm{Pd}_{50} \mathrm{Cu}_{50}, \mathrm{Pd}_{88} \mathrm{Co}_{12}, \mathrm{Pd}_{56} \mathrm{Cu}_{38} \mathrm{Co}_{6}, \mathrm{Pd}_{59} \mathrm{Cu}_{30} \mathrm{Co}_{11}, \mathrm{Pd}_{62} \mathrm{Cu}_{16} \mathrm{Co}_{22}$, commercial Pt/C, and Pd black with a scan rate of $50 \mathrm{mV} \mathrm{s}^{-1}$ in $0.1 \mathrm{~mol} \mathrm{~L}^{-1}(\mathrm{M})$ perchloric acid $\left(\mathrm{HClO}_{4}\right)+0.5 \mathrm{M}$ formic acid $(\mathrm{HCOOH})$ solution at room temperature. $\mathbf{c}$ Histograms of formic acid oxidation (FAO) specific activity and mass activity. Error bars are \pm s.d. $\mathbf{d}$ Current-time curves of the as-synthesized $\mathrm{Pd}_{50} \mathrm{Cu}_{50}, \mathrm{Pd}_{88} \mathrm{Co}_{12}, \mathrm{Pd}_{56} \mathrm{Cu}_{38} \mathrm{Co}_{6}, \mathrm{Pd}_{59} \mathrm{Cu}_{30} \mathrm{Co}_{11}, \mathrm{Pd}_{62} \mathrm{Cu}_{16} \mathrm{Co}_{22}, \mathrm{commercial} \mathrm{Pt} / \mathrm{C}$, and $\mathrm{Pd}$ black recorded at $0.25 \mathrm{~V}$ for $2500 \mathrm{~s}$ in $0.1 \mathrm{M} \mathrm{HClO}_{4}+0.5 \mathrm{M} \mathrm{HCOOH}$ solution at room temperature 
with a scan rate of $50 \mathrm{mV} \mathrm{s}^{-1}$ at room temperature in $0.1 \mathrm{M} \mathrm{KOH}+0.1 \mathrm{M} \mathrm{CH}_{3} \mathrm{OH}$ or $0.1 \mathrm{M} \mathrm{KOH}+0.1 \mathrm{M} \mathrm{CH}_{3} \mathrm{CH}_{2} \mathrm{OH}$, and the potential was scanned from 0.03 to $1.43 \mathrm{~V}$ (versus RHE), after this, using RDE at a rotation rate of $1600 \mathrm{rpm}$, and the potential was scanned from 0.13 to $1.03 \mathrm{~V}$ (versus RHE) at a scan rate of $10 \mathrm{mV} \mathrm{s}^{-1}$.

\section{Data availability}

All relevant data are available from the corresponding author upon reasonable request.

Received: 4 February 2018 Accepted: 13 August 2018

Published online: 12 September 2018

\section{References}

1. Steele, B. C. \& Heinzel, A. Materials for fuel cell technologies. Nature 414, 345-352 (2001).

2. Othman, R., Dicks, A. L. \& Zhu, Z. Nonprecious metal catalysts for the PEM fuel cell cathode. Int. J. Hydrogen Energy 37, 357-372 (2012).

3. Chen, A. \& Holthindle, P. Platinum-based nanostructured materials: synthesis, properties, and applications. Chem. Rev. 110, 3767-3804 (2010).

4. Zhang, Z. et al. One-pot synthesis of highly anisotropic fivefold-twinned $\mathrm{PtCu}$ nanoframes used as a bifunctional electrocatalyst for oxygen reduction and methanol oxidation. Adv. Mater. 28, 8712-8717 (2016).

5. Zhang, N. et al. Superior bifunctional liquid fuel oxidation and oxygen reduction electrocatalysis enabled by PtNiPd core-shell nanowires. Adv. Mater. 29, 1603774 (2016).

6. Liu, T. et al. Monodispersed sub-5.0 nm PtCu nanoalloys as enhanced bifunctional electrocatalysts for oxygen reduction reaction and ethanol oxidation reaction. Nanoscale 9, 2963-2968 (2017).

7. Huang, X. et al. High-performance transition metal-doped $\mathrm{Pt}_{3} \mathrm{Ni}$ octahedra for oxygen reduction reaction. Science 348, 1230-1234 (2015).

8. Casado-Rivera, E. et al. Electrocatalytic activity of ordered intermetallic phases for fuel cell applications. J. Am. Chem. Soc. 126, 4043-4049 (2004)

9. Wang, Y. et al. Carbon-supported Pt-based alloy electrocatalysts for the oxygen reduction reaction in polymer electrolyte membrane fuel cells: particle size, shape, and composition manipulation and their impact to activity. Chem. Rev. 115, 3433-3467 (2015).

10. Bianchini, C. \& Shen, P. K. ChemInform abstract: palladium-based electrocatalysts for alcohol oxidation in half cells and in direct alcohol fuel cells. Chem. Rev. 109, 4183-4206 (2009).

11. Antolini, E. Palladium in fuel, cell catalysis. Energy Environ. Sci. 2, 915-931 (2009).

12. Suo, Y., Zhuang, L. \& Lu, J. First-principles considerations in the design of Pd alloy catalysts for oxygen reduction. Angew. Chem. Int. Ed. 46, 2862-2864 (2007).

13. Maheswari, S., Karthikeyan, S., Murugan, P., Sridhar, P. \& Pitchumani, S. Carbon-supported Pd-Co as cathode catalyst for APEMFCs and validation by DFT. Phys. Chem. Chem. Phys. 14, 9683-9695 (2012).

14. Holewinski, A., Idrobo, J. C. \& Linic, S. High-performance Ag-Co alloy catalysts for electrochemical oxygen reduction. Nat. Chem. 6, 828-834 (2014).

15. Ahn, M. et al. Rhodium-tin binary nanoparticle-a strategy to develop an alternative electrocatalyst for oxygen reduction. ACS Catal. 7, 5796-5801 (2017).

16. Narayanamoorthy, B. et al. Enhanced intrinsic activity and stability of $\mathrm{Au}-\mathrm{Rh}$ bimetallic nanostructures as a supportless cathode electrocatalyst for oxygen reduction in alkaline fuel cells. ACS Sustain. Chem. Eng. 4, 6480-6490 (2016).

17. Yan, Y. et al. Kinetically controlled growth of cubic and octahedral Rh-Pd alloy oxygen reduction electrocatalysts with high activity and durability. Nanoscale 7, 301-307 (2015).

18. Qi, Y. Wu et al. Facile synthesis of Rh-Pd alloy nanodendrites as highly active and durable electrocatalysts for oxygen reduction reaction. Nanoscale $\mathbf{6}$, 7012-7018 (2014).

19. Li, M. et al. Ultrafine jagged platinum nanowires enable ultrahigh mass activity for the oxygen reduction reaction. Science 354, 1414-1419 (2016).

20. Wang, X., Yang, J., Yi, H., Song, R. \& Tang, Z. "Raisin bun"-like nanocomposites of palladium clusters and porphyrin for superior formic acid oxidation. Adv. Mater. 25, 2728-2732 (2013).

21. Feng, L. et al. Nanostructured palladium catalyst poisoning depressed by cobalt phosphide in the electrooxidation of formic acid for fuel cells. Nano Energy 30, 355-361 (2016).

22. Wang, C., Chen, D. P., Sang, X., Unocic, R. R. \& Skrabalak, S. E. Sizedependent disorder-order transformation in the synthesis of monodisperse intermetallic PdCu nanocatalysts. ACS Nano 10, 6345-6353 (2016).

23. Zhang, L. et al. Pd-Cu bimetallic tripods: a mechanistic understanding of the synthesis and their enhanced electrocatalytic activity for formic acid oxidation. Adv. Funct. Mater. 24, 7520-7529 (2015).
24. Chen, Y. et al. High-yield synthesis of crystal-phase-heterostructured $4 \mathrm{H} / \mathrm{fcc}$ $\mathrm{Au} @ \mathrm{Pd}$ core-shell nanorods for electrocatalytic ethanol oxidation. Adv. Mater. 29, 1701331 (2017).

25. Dai, Y. et al. Carbon monoxide-assisted synthesis of single-crystalline Pd tetrapod nanocrystals through hydride formation. J. Am. Chem. Soc. 134, 7073-7080 (2012).

26. Du, C., Chen, M., Wang, W. \& Yin, G. Nanoporous PdNi alloy nanowires as highly active catalysts for the electrooxidation of formic acid. ACS Appl. Mater. Interfaces 3, 105-109 (2011).

27. Lu, Y., Jiang, Y., Gao, X., Wang, X. \& Chen, W. Strongly coupled Pd nanotetrahedron/tungsten oxide nanosheet hybrids with enhanced catalytic activity and stability as oxygen reduction electrocatalysts. J. Am. Chem. Soc. 136, 11687-11697 (2014).

28. Jiang, R. Tran, Mcclure, D. T. J. P. \& Chu, D. A class of (Pd-Ni-P) electrocatalysts for the ethanol oxidation reaction in alkaline media. ACS Catal. 4, 2577-2586 (2014)

29. Jin, M., Zhang, H., Xie, Z. \& Xia, Y. Palladium concave nanocubes with highindex facets and their enhanced catalytic properties. Angew. Chem. Int. Ed. 123, 7850-7854 (2011).

30. Zhou, Z., Kang, X., Song, Y. \& Chen, S. Butylphenyl-functionalized palladium nanoparticles as effective catalysts for the electrooxidation of formic acid. Chem. Commun. 47, 6075-6077 (2011).

31. Huang, X. et al. Free-standing palladium nanosheets with plasmonic and catalytic properties. Nat. Nanotech. 6, 28-32 (2011).

32. Chen, L. et al. Nanoporous PdNi bimetallic catalyst with enhanced electrocatalytic performances for electrooxidation and oxygen reduction reactions. Adv. Funct. Mater. 21, 4364-4370 (2011).

33. Mazumder, V., MoreK. L. \& SunS. et al. A facile synthesis of MPd $(\mathrm{M}=\mathrm{Co}$, $\mathrm{Cu})$ nanoparticles and their catalysis for cormic acid oxidation. Nano Lett. 12, 1102-1106 (2012).

34. Ghosh, A., Chandran, P. \& Ramaprabhu, S. Palladium-nitrogen coordinated cobalt alloy toward hydrogen oxidation and oxygen reduction reactions with high catalytic activity in renewable energy generations of proton exchange membrane fuel cell. Appl. Energy 208, 37-48 (2017).

35. Koenigsmann, C. \& Wong, S. S. Tailoring chemical composition to achieve enhanced methanol oxidation reaction and methanol-tolerant oxygen reduction reaction performance in palladium-based nanowire systems. ACS Catal. 3, 2031-2040 (2013).

36. Guo, C. X., Zhang, L. Y., Miao, J., Zhang, J. \& Li, C. M. DNA-functionalized graphene to guide growth of highly active Pd nanocrystals as efficient electrocatalyst for direct formic acid fuel cells. Adv. Energy Mater. 3, 167-171 (2013).

37. Zheng, Y. et al. Component-controlled synthesis and assembly of $\mathrm{Cu}-\mathrm{Pd}$ nanocrystals on graphene for oxygen reduction reaction. ACS Appl. Mater. Interfaces 7, 5347-5357 (2015).

38. Zhang, Y. et al. Seedless growth of palladium nanocrystals with tunable structures: from tetrahedra to nanosheets. Nano Lett. 15, 7519-7525 (2015).

39. Yang, N. et al. Synthesis of ultrathin PdCu alloy nanosheets used as a highly efficient electrocatalyst for formic acid oxidation. Adv. Mater. 29, 1700769 (2017).

40. Zuo, Y. et al. Atomic vacancies control of Pd-based catalysts for enhanced electrochemical performance. Adv. Mater. 30, 1704171 (2018).

41. Liu, H., Koenigsmann, C., Adzic, R. R. \& Wong, S. S. Probing ultrathin onedimensional $\mathrm{Pd}-\mathrm{Ni}$ nanostructures as oxygen reduction reaction catalysts. ACS Catal. 4, 2544-2555 (2014).

42. Liu, H., Zheng, Y., Wang, G. \& Qiao, S. Z. A three-component nanocomposite with synergistic reactivity for oxygen reduction reaction in alkaline solution. Adv. Energy Mater. 5, 618-622 (2015).

43. Jiang, K. et al. Ordered PdCu-based nanoparticles as bifunctional oxygen reduction and ethanol-oxidation electrocatalysts. Angew. Chem. Int. Ed. 55, 9030-9035 (2016)

44. Wang, R. et al. One-pot solvothermal synthesis of $\mathrm{PdCu}$ nanocrystals with enhanced electrocatalytic activity toward glycerol oxidation and hydrogen evolution. Int. J. Hydrogen Energy 42, 6695-6704 (2017).

45. Dai, Q. \& Tang, J. The optical and magnetic properties of $\mathrm{CoO}$ and $\mathrm{Co}$ nanocrystals prepared by a facile technique. Nanoscale 5, 7512-7519 (2013).

46. Xiao, W. et al. Optimizing the ORR activity of Pd-based nanocatalysts by tuning their strain and particle size. J. Mater. Chem. A 5, 9867-9872 (2017).

47. Zhao, W. et al. Highly active and durable $\mathrm{Pt}_{72} \mathrm{Ru}_{28}$ porous nanoalloy assembled with sub-4.0 nm particles for methanol oxidation. Adv. Energy Mater. 7, 1601593 (2017).

48. Zhang, N. et al. Oxide defect engineering enables to couple solar energy into oxygen activation. J. Am. Chem. Soc. 138, 8928-8935 (2016).

49. Lan, J., Wang, K., Yuan, Q. \& Wang, X. Composition-controllable synthesis of defect-rich PtPdCu nanoalloys with hollow cavities as superior electrocatalysts for alcohol oxidation. Mater. Chem. Front. 1, 1217-1222 (2017).

50. Xu, G. et al. Morphological and interfacial control of platinum nanostructures for electrocatalytic oxygen reduction. ACS Catal. 6, 5260-5267 (2016). 
51. Lim, B. et al. Pd-Pt bimetallic nanodendrites with high activity for oxygen reduction. Science 324, 1302-1305 (2009).

52. Xue, Ha et al. Fabrication of PdCo bimetallic nanoparticles anchored on threedimensional ordered $\mathrm{N}$-doped porous carbon as an efficient catalyst for oxygen reduction reaction. ACS Appl. Mater. Interfaces 8, 20766-20771 (2016).

53. Wang, A. et al. Palladium-cobalt nanotube arrays supported on carbon fiber cloth as high-performance flexible electrocatalysts for ethanol oxidation. Angew. Chem. Int. Ed. 54, 3669-3673 (2015).

54. Li, J. et al. Surface evolution of a Pt-Pd-Au electrocatalyst for stable oxygen reduction. Nat. Energy 2, 17111 (2017).

55. Fernández, J. L., Walsh, D. A. \& Bard, A. J. Thermodynamic guidelines for the design of bimetallic catalysts for oxygen electroreduction and rapid screening by scanning electrochemical microscopy. M-Co (M: Pd, Ag, Au). J. Am. Chem. Soc. 127, 357-365 (2005).

56. Chen, B., Cheng, D. \& Zhu, J. Synthesis of PtCu nanowires in nonaqueous solvent with enhanced activity and stability for oxygen reduction reaction. $J$. Power Sources 267, 380-387 (2014).

57. Huang, S., Yang, N., Wang, S., Sun, Y. \& Zhu, Y. Tuning the synthesis of platinum-copper nanoparticles with a hollow core and porous shell for the selective hydrogenation of furfural to furfuryl alcohol. Nanoscale $\mathbf{8}$, 14104-14108 (2014).

58. Chen, S., Su, H., Wang, Y., Wu, W. \& Zeng, J. Size-controlled synthesis of platinum-copper hierarchical trigonal bipyramid nanoframes. Angew. Chem. Int. Ed. 54, 108-113 (2015).

59. $\mathrm{Bu}, \mathrm{L}$. et al. Biaxially strained $\mathrm{PtPb} / \mathrm{Pt}$ core/shell nanoplate boosts oxygen reduction catalysis. Science 354, 1410-1414 (2016).

60. $\mathrm{Wu}, \mathrm{J}$. et al. Surface lattice-engineered bimetallic nanoparticles and their catalytic properties. Chem. Soc. Rev. 41, 8066-8074 (2012).

61. Stamenkovic, V. R. et al. Trends in electrocatalysis on extended and nanoscale Pt-bimetallic alloy surfaces. Nat. Mater. 6, 241-247 (2007).

62. Mavrikakis, M., Hammer, B. \& Nørskov, J. K. Effect of strain on the reactivity of metal surfaces. Phys. Rev. Lett. 81, 2819-2822 (1998).

\section{Acknowledgments}

This work was supported by the National Natural Science Foundation of China (21571038, 21361005, 21431003, and 21521091), National Key R\&D Program of China (2017YFA0700101 and 2016YFA0202801), the Open Fund of the Key Lab of Organic Optoelectronics \& Molecular Engineering (Tsinghua University) and State Key
Laboratory of Physical Chemistry of Solid Surfaces (201520). We also thank Professor Zhi-You Zhou (Xiamen University) for the help of ORR experiments and discussion.

\section{Author contributions}

C.L. synthesized the catalysts, prepared the fuel cell test materials and performed electrocatalytic tests. C.L., B.N., T.H., S.Z., Y.L., and L.G. performed the structure characterizations (TEM, HRTEM, ICP, XPS, XRD, and EDS). Q.Y. and X.W. wrote and edited the manuscript and Supplementary information. All authors contributed to discussions about the results and the manuscript. The project was conceived and supervised by Q.Y. and X.W.

\section{Additional information}

Supplementary Information accompanies this paper at https://doi.org/10.1038/s41467018-06043-1.

Competing interests: The authors declare no competing interests.

Reprints and permission information is available online at http://npg.nature.com/ reprintsandpermissions/

Publisher's note: Springer Nature remains neutral with regard to jurisdictional claims in published maps and institutional affiliations.

(c) Open Access This article is licensed under a Creative Commons Attribution 4.0 International License, which permits use, sharing, adaptation, distribution and reproduction in any medium or format, as long as you give appropriate credit to the original author(s) and the source, provide a link to the Creative Commons license, and indicate if changes were made. The images or other third party material in this article are included in the article's Creative Commons license, unless indicated otherwise in a credit line to the material. If material is not included in the article's Creative Commons license and your intended use is not permitted by statutory regulation or exceeds the permitted use, you will need to obtain permission directly from the copyright holder. To view a copy of this license, visit http://creativecommons.org/ licenses/by/4.0/.

(C) The Author(s) 2018 